\title{
Retinoblastoma: Masalah dan hambatan dalam mendiagnosis
}

\author{
Mohammad Haikal Bakry¹, Riana Rahmadhany ${ }^{2}$
}

\begin{abstract}
ABSTRAK
Retinoblastoma adalah keganasan intraokular yang paling sering dialami oleh neonatus dan anak-anak, dengan insidens terjadinya yaitu 1 per 15.000-20.000 kelahiran dan sekitar 3\% dari total keganasan yang terjadi pada anak. Diagnosis dan penanganan retinoblastoma yang terlambat terjadi di negara-negara berkembang termasuk Indonesia mengakibatkan terjadinya metastasis ekstraokular, kehilangan penglihatan dan kematian. Pada negara-negara berkembang, kira-kira setengah populasi anak yang terdiagnosis retinoblastoma meninggal, diduga karena baru terdiagnosis saat stadium penyakit yang sudah lanjut, sementara hanya 3-4\% anak yang terdiagnosis di negara maju (Amerika dan Eropa) meninggal karena lebih awal dalam mendiagnosis dan penatalaksaan yang lebih komprehensif.

Adanya hambatan dalam mendiagnosis secara dini pada negara berkembang dikarenakan belum baiknya sistem asuransi kesehatan, kurangnya komunikasi dan kerjasama pihak- pihak yang terlibat, masih terbatasnya peralatan penunjang diagnosis dan kurang efisiennya sistem rujukan. Hambatan lain termasuk faktor pendidikan, kultural dan ekonomi.

Pemberian penanganan yang optimal pada retinoblastoma adalah suatu hal yang kompleks dan memerlukan sebuah tim yang terdiri dari berbagai macam bidang dan disiplin ilmu. Namun pembentukan tim yang seperti itu tentu saja akan menghadapi berbagai macam tantangan khususnya pada keadaan dan daerah yang memiliki sumber daya yang terbatas.

\section{${ }^{1,2}$ Klinik Pratama Mulya,} Pekanbaru, Riau, Indonesia

\section{Korespondensi:}

Mohammad Haikal Bakry

Klinik Pratama Mulya, Pekanbaru, Riau, Indonesia

Jalan H. Imam Munandar No. 320

N, Pekanbaru, Riau

Email: bakryhaikal@gmail.com

J Biomedika Kesehat 2019;2(4):162-

168

DOI: 10.18051/JBiomedKes.2019.

v2.162-168

pISSN: 2621-539X / eISSN: 2621-5470

Artikel akses terbuka (open access) ini didistribusikan di bawah lisensi Creative Commons Attribution 4.0 International (CC-BY 4.0)
\end{abstract}

Kata kunci: retinoblastoma, leukokoria, akses kesehatan, negara berkembang 


\section{ABSTRACT}

\section{Retinoblastoma: Problems and challenges in diagnosing}

Retinoblastoma is the most frequent intraocular malignancy experienced by neonates and children, with an incidence of 1 per 15.000-20.000 births and about 3\% of the total malignancies that occur in children. Late diagnosis and treatment that often occurs in developing countries including Indonesia can lead to extraocular metastases, loss of vision and also death. In developing countries, approximately half the population of children diagnosed with retinoblastoma died, presumably because it was only diagnosed when advanced disease stage, while only $3-4 \%$ of children diagnosed in developed countries (America and Europe) died due to earlier in more comprehensive diagnosis and management.

There are obstacles in diagnosing early in developing countries due to lack of a good health insurance system, lack of communication and cooperation of the parties involved, limited diagnostic support equipment and lack of a referral system. Other obstacles include education, cultural and economic factors.

Providing optimal treatment for retinoblastoma is a complex matter and requires a team consisting of various fields and disciplines. However, the formation of such a team will certainly face a variety of challenges, especially in circumstances and regions that have limited resources.

Keywords: retinoblastoma, leukocoria, health access, developing country

\section{PENDAHULUAN}

Lebih dari satu abad yang lalu, retinoblastoma dianggap sebagai penyakit yang sudah mendekati kematian. Retinablastoma pertama kali diidentifikasi tahun 1500an dan didefinisikan sebagai kesatuan klinikopatologis tahun 1809. Sampai di pertengahan tahun 1900, pengetahuan berkembang secara sporadik. Dengan adanya diagnosis dini menggunakan oftalmoskopi indirek dan tatalaksana teknik enukleasi berperan besar meningkatkan angka harapan hidup dari 5\% pada tahun 1896 menjadi $81 \%$ pada tahun 1967..$^{(1,2)}$

Retinoblastoma adalah keganasan intraokular yang paling sering dialami oleh neonatus dan anak-anak, insidens terjadinya yaitu 1 per 15.000-20.000 kelahiran dan sekitar $3 \%$ dari total keganasan yang terjadi pada anak. (2,3) Diperkirakan 7000-8000 anak mengalami retinoblastoma tiap tahunnya di seluruh dunia dengan 3000-4000 diantaranya meninggal. ${ }^{(4)}$ Data di RS Cipto Mangunkusumo, Divisi Oftalmologi, menunjukkan insidens berkisar pada 165 kasus dalam periode 1993-2000 dan angka ini cenderung meningkat menjadi sekitar 30-40 kasus per tahun. (5) Studi di Amerika serikat, dilakukan analisis epidemiologi dari 1.452 kasus retinoblastoma dalam kurun waktu antara tahun 1973 sampai 2009, didapatkan kebanyakan kasus didiagnosis sebelum pasien berumur 2 tahun dan tidak didapatkan adanya hubungan secara umum mengenai umur pasien saat didiagnosis dengan keberhasilan pasien untuk bertahan hidup. Tidak didapatkan perbedaan jumlah kasus dan keberhasilan bertahan hidup yang signifikan antara laki-laki dan perempuan. ${ }^{(6,7)}$

\section{Masalah dan hambatan dalam mendiagnosis}

Terdapat tiga penyebab utama yang menyebabkan kematian pada retinoblastoma, yaitu keganasan sekunder, pineoblastoma dan metastasis. ${ }^{(8)}$ Angka harapan hidup pada retinoblastoma dilaporkan melebihi 95\% ketika didiagnosis secara dini pada tahap intraokular. Namun, diagnosis dan penanganan yang terlambat yang sering terjadi di negara-negara berkembang termasuk Indonesia dapat mengakibatkan terjadinya metastasis ekstraokular, kehilangan penglihatan dan kematian. . $^{(3,4)}$

Pada negara-negara berkembang, kirakira setengah populasi anak yang terdiagnosis retinoblastoma meninggal, diduga karena baru terdiagnosis saat stadium penyakit yang sudah lanjut, sementara hanya 3-4\% anak yang terdiagnosis di Amerika dan Eropa meninggal karena lebih awal dalam mendiagnosis dan penatalaksaan yang lebih komprehensif. (9,10) $^{(2)}$ Penundaan penentuan diagnosis yang terjadi lebih dari 6 bulan setelah muncul tanda pertama dihubungkan dengan terjadinya penyebaran ekstraokular dan $70 \%$ mortalitas. Adanya hambatan dalam mendiagnosis secara dini pada negara berkembang dikarenakan belum baiknya sistem asuransi kesehatan, kurangnya komunikasi dan kerjasama pihak- pihak yang terlibat, masih terbatasnya peralatan penunjang diagnosis dan kurang efisiennya sistem rujukan. Hambatan lain termasuk faktor pendidikan, kultural dan ekonomi. (9)

Kurangnya edukasi terhadap orang tua dan kurangnya kesadaran tentang tanda dan gejala menyebabkan terlambatnya penanganan medis 
terhadap pasien. Penyebab lain yaitu orang tua lebih memilih untuk mencari pengobatan alternatif akibat keterbatasan akses maupun alasan kultural yang berdampak keterlambatan mencari pengobatan secara medis. ${ }^{(9)}$

Adanya konflik prioritas juga menjadi hambatan proses diagnosis retinoblastoma. Orang tua akhirnya harus memprioritaskan kebutuhan lain untuk bertahan hidup, seperti makanan maupun biaya sekolah untuk saudaranya yang lain. Orang tua juga mungkin tidak dapat mengikuti segala prosedur diagnostik karena keterbatasan waktu, biaya untuk berobat dan transportasi ke rumah sakit. Konflik kepentingan dan politik juga dapat berpengaruh terhadap kebijakan pelayanan medis serta ketersediaan fasilitas untuk diagnostik dan pengobatan. Pengertian orang tua dan keluarga mengenai rencana penatalaksanaan terhadap pasien dan kepercayaan sepenuhnya terhadap tim medis merupakan komponen vital proses pengobatan retinoblastoma. Penolakan tindakan enukleasi telah terdokumentasi menjadi hambatan utama dalam penatalaksaan retinoblastoma pada kira-kira $40 \%$ kasus di daerah-daerah berpenghasilan rendah. ${ }^{(9)}$

Penanganan optimal retinoblastoma adalah suatu hal yang kompleks dan memerlukan tim yang terdiri dari berbagai macam bidang dan disiplin ilmu. Kerjasama tersebut termasuk dalam bidang kesehatan (dokter spesialis mata, perawat, ahli onkologi), akademisi (peneliti), survivor, keluarga dan dukungan dari pemerintah. Namun, pembentukan tim yang seperti itu tentu saja akan menghadapi berbagai macam tantangan khususnya pada keadaan dan daerah yang memiliki sumber daya yang terbatas. ${ }^{(11)}$ Kemampuan public health dalam mengintervensi kesadaran publik mengenai retinoblastoma telah banyak diketahui dan terdokumentasi. Kampanye nasional mengenai edukasi terhadap retinoblastoma di Honduras menurunkan rata-rata waktu penanganan pasien sejak muncul gejala sampai terdiagnosis yaitu dari 7.2 bulan menjadi 5.5 bulan dan menurunkan proporsi kasus retinoblastoma ekstraokular dari $73 \%$ menjadi $35 \%$. Adanya kampanye nasional untuk diagnosis dini pada retinoblastoma di Brazil dengan memberikan pelatihan kepada guru-guru di sekolah maupun para petugas kesehatan masyarakat untuk bisa mengenali gejala retinoblastoma berhasil menurunkan kasus ekstraokular dari 56\% menjadi dibawah 10\% dalam kurun waktu kurang dari 20 tahun..$^{(9)}$ Adanya perencanaan dan pengaturan strategi nasional yang baik dapat mengurangi insiden terjadinya kanker dan meningkatkan kualitas hidup seseorang yang menderita kanker. ${ }^{(11)}$ Salah satu contoh sukses dalam mengembangkan strategi nasional adalah di China. Peningkatan dalam hal efisiensi dan kolaborasi nasional dari tahun 2006 sampai 2014 telah menuntun pemberian standar klasifikasi dan penatalaksanaan pada 2.097 pasien baru yang mengalami retinoblastoma yang meningkatkan angka harapan hidup pada anak yang mengalami retinoblastoma. $^{(12)}$

Hampir setengah dari anak yang mengalami retinoblastoma mempunyai resiko untuk mengalami kanker sekunder dan saudara kandung maupun keturunannya juga mempunyai resiko yang tinggi untuk mengalami hal yang sama. ${ }^{(13)}$ Pemeriksaan genetik prenatal memungkinkan untuk memprediksi apakah anak akan mengalami retinoblastoma sebelum anak itu lahir apabila diketahui ayah atau ibu anak tersebut mengalami mutasi germline. Mata dari janin tersebut dapat diskrining dengan pemeriksaan USG ataupun MRI pada trimester ketiga. ${ }^{(14)}$

Pemahaman mengenai kelainan genetik pada retinoblastoma sangat krusial untuk dipahami, agar pasien dan keluarga yang mengalami mendapatkan penanganan yang adekuat. ${ }^{(13)}$ Pemeriksaan genetik dapat mengidentifikasi penyebab genetik dari retinoblastoma yang bisa digunakan untuk menskrining anggota keluarga yang lain termasuk orang tua, saudara kandung, dan juga keturunan dari individu itu sendiri. ${ }^{(14)}$

Pada suatu studi yang mengeksplor mengenai pemahaman, pengalaman dan sikap tentang faktor genetik retinoblastoma pada pasien-pasien dan keluarga yang berhasil survive didapatkan bahwa pemahaman mengenai faktor genetik pada retinoblastoma bervariasi dan umumnya masih terbatas. Dibutuhkan adanya pemberian informasi secara menyeluruh dan mudah dipahami oleh pasien dan keluarga. ${ }^{(15)}$ Adanya jadwal yang lebih sering dan teratur untuk berkonsultasi tidak hanya dapat meningkatkan pengetahuan dan pemahaman tetapi juga dapat memberikan rasa nyaman dan kesempatan untuk menanyakan perihal informasi yang dibutuhkan pasien. Beberapa partisipan memberikan saran 
agar pemberian informasi dan pemahaman mengenai retinoblastoma dapat dilakukan dengan cara yang lebih kreatif dan berbeda seperti flipbook untuk anak-anak, konsultasi genetik yang mengikutsertakan anggota keluarga yang lain untuk berpartisipasi, pemberian informasi melalui Youtube mengenai pertanyaan yang umum mengenai retinoblastoma. ${ }^{(15)}$

Akses untuk mendapatkan tes genetik khususnya pelayanan konseling genetik sangat bervariasi secara global. Di negara maju mudah didapatkan aksesnya tetapi untuk negara berkembang pemeriksaan genetik untuk penyakit seperti retinoblastoma tidak tersedia dan juga kurangnya pelatihan khusus mengenai kelainan genetik menyebabkan ketidakmampuan untuk memberikan konseling yang baik. ${ }^{(13)}$ Usaha lain yang dapat dilakukan berupa inovasi low tech yaitu, memasukan gambar leukokoria di dalam buku kesehatan anak yang didapatkan ibu setelah melahirkan anaknya ataupun inovasi hightech seperti portable eye examination, aplikasi smartphone yang dapat membantu pengguna untuk mengenali dan mendeteksi gangguan mata termasuk retinoblastoma. ${ }^{(16)}$

Pada anak-anak yang mempunyai resiko retinoblastoma seharusnya dilakukan skrining sedini mungkin dengan pemeriksaan funduksopi untuk bisa mendiagnosis tumor lebih awal. Studi penelitian yang dilakukan di Paris dibuat suatu pedoman mengenai jadwal skrining pada anak atau bayi yang baru lahir yang mempunyai riwayat keluarga menderita retinoblastoma. Hasilnya dengan melakukan skrining secara berkala dan intensif mampu mengurangi jumlah tindakan enukleasi dan external beam radiation (EBRT), walaupun masih belum mampu untuk mengurangi penggunaan kemoterapi sistemik ataupun mendapatkan ketajaman visual yang lebih baik. ${ }^{(17)}$ Hasil skrining negatif pada pemeriksaan mata anak tidak berarti anak tersebut bebas dari tumor karena masih mungkin tumor belum muncul atau tumor tersebut berada di perifer dan tidak terlihat (negatif palsu). ${ }^{(12)}$ Dengan dilakukannya pemeriksaan skrining secara intensif, mampu menurunkan umur saat pertama kali didiagnosis dan didapatkan pada grade yang rendah. ${ }^{(17)}$

\section{Dasar diagnosis}

Retinoblastoma diinisiasi oleh hilangnya fungsi gen penekan tumor RB1. ${ }^{(13)}$ Beberapa kasus retinoblastoma disebabkan gen RB1 yang bermutasi sementara lainnya disebabkan karena amplifikasi somatik dari gen MYCN. Saat ini peneliti genetik menemukan bahwa retinoblastoma dapat terjadi ketika MYCN onkogen mengalami amplifikasi bahkan tanpa adanya RB1 yang bermutasi. Kasus tersebut relatif jarang terjadi, muncul kurang dari 3\% dari kasus retinoblastoma unilateral..$^{(7)}$ Semua kasus retinoblastoma bilateral dan kira-kira $10 \%$ dari total kasus unilateral diperkirakan membawa mutasi germinal dan menurunkannya ke anak-anak mereka. ${ }^{(17)}$ Dengan diturunkannya satu alel gen RB1 yang bermutasi sangat berpeluang menjadi faktor predisposisi terjadinya retinoblastoma yang terjadi setelah satu alel lainnya bermutasi, yang menyebabkan terjadinya proliferasi yang tidak terkontrol. ${ }^{(12)}$

Hanya 5-10\% kasus retinoblastoma yang herediter dan kebanyakan kasus disebabkan oleh mutasi baru yang terjadi pada masa perkembangan janin. ${ }^{(15)}$ Tidak seperti pasien retinoblastoma nonherediter, pasien-pasien retinoblastoma herediter yang berhasil bertahan hidup mempunyai resiko yang tinggi untuk mengalami keganasan sekunder dengan besar mortalitas kumulatifnya sebesar $17 \%$. Beberapa studi juga menghubungkan terjadinya keganasan pada anak akibat penggunaan radiasi. Walaupun kemungkinannya kecil, sebaiknya pasien-pasien retinoblastoma menghindari penggunaan radiasi seminimal mungkin karena seperti yang kita tahu pasien tersebut mempunyai ketidakstabilan genetik. Lebih jauh lagi anakanak yang dalam pemberian radioterapi akan mengalami abnormalitas dalam pertumbuhan dan perkembangan tulang craniofacial, yang berakibat adanya deformitas pada wajah. ${ }^{(18)}$

Perkembangan retinoblastoma dapat menempel dibawa retina (subretinal seeds) ataupun ke vitreus (vitreus seeds). Tumor yang besar dapat mengangkat dan menyebabkan ablasi pada retina, inflamasi, nekrosis dan kadang ptisis bulbi. Tumor dapat menyebar keluar dari mata dengan melewati batas-batas retina seperti membran Bruch, menginvasi koroid dan pembuluh darah. Jalur lain yang biasa terjadi yaitu melalui nervus optikus ke otak dan cairan serebrospinal. ${ }^{(16)}$ Baik atau tidaknya fungsi penglihatan tergantung dari besarnya tumor dan letak tumor secara anatomi serta hubungannya dengan makula dan diskus optikus. ${ }^{(18)}$ Metastasis 
terjadi terutama melalui invasi langsung ke kiasma optikum, nervus optikus intrakranial, supra cella sisterna, meningens dan bahkan secara lokal melalui parenkim otak. Sementara metastasis dapat terjadi secara hematogen yang melibatkan tulang, sumsum tulang dan paru-paru. ${ }^{(3)}$

Semakin tingginya grade tumor dihubungkan dengan semakin rendahnya angka keberhasilan hidup pasien. Pasien yang mengalami retinoblastoma bilateral akan menurunkan angka keberhasilan hidup dan meningkatkan insiden terjadinya keganasan non-okular sekunder, yaitu yang paling sering terjadi adalah pineoblastoma dan osteosarkoma, dibandingkan dengan pasien yang mengalami retinoblastoma unilateral. ${ }^{(6)}$ Resiko pasien retinoblastoma mengalami trilateral retinoblastoma adalah kurang dari $0.5 \%$ pada pasien unilateral yang sporadik, 5\%-13\% pada kasus bilateral yang sporadik dan 5\%-15\% pada kasus familial bilateral. ${ }^{(19)}$ Retinoblastoma orbital adalah salah satu yang berperan besar terhadap mortalitas dan memberikan prognosis yang buruk terhadap kehidupan. Dengan adanya invasi retinoblastoma ke orbital dihubungkan dengan meningkatnya 10 sampai $27 \mathrm{x}$ resiko metastasis dibandingkan kasus tanpa adanya keterlibatan orbital. $^{(1)}$

Disarankan untuk selalu melakukan skrining retinoblastoma dengan melihat adanya "red reflex" pada pemeriksaan menggunakan oftalmoskopi. Tanda yang paling sering muncul adalah leukokoria (white pupil), ketika orang tua melihat ada bayangan atau pantulan yang aneh pada mata anaknya. Tanda berikutnya yang sering muncul yaitu adanya strabismus. Selain itu dapat muncul juga perubahan warna iris, pembesaran kornea dan mata karena adanya peningkatan tekanan atau adanya inflamasi orbital. Yang paling akhir yaitu menonjolnya mata keluar dari orbit menjadi tanda yang umum pada kasus yang terlambat, hal ini terjadi jika kurang adanya perhatian maupun sumber daya yang inadekuat. Oftalmoskopi indirek dengan pemberian dilator pupil biasa dilakukan untuk mendiagnosis adanya retinoblastoma. Pada retinoblastoma familial, skrining prenatal pemeriksaan DNA dapat diperoleh dari cairan amnion pada masa kehamilan. ${ }^{(12)}$

Disamping pentingnya dokter melakukan skrining, salah satu cara paling efektif untuk mendeteksi adanya retinoblastoma adalah dengan melihat bayangan mata anak melalui foto, dimana proporsi paling besar terdeteksinya kasus retinoblastoma di Amerika Serikat (sekitar $80 \%$ ) adalah melalui laporan orang tua yang memperhatikan adanya leukokoria/bayangan putih pada mata anaknya di foto. ${ }^{(4)}$ Walaupun kondisi lain juga bisa menjadi penyebab timbulnya leukokoria seperti coat's disease, katarak, korioretinitis, dan persistent fetal vasculature, tetapi penyebab munculnya leukokoria pada anak terutama di bawah 5 tahun harus dipertimbangkan karena adanya retinoblastoma. Leukokoria (white eye atau cat eye) dihubungkan dengan adanya retinoblastoma stadium lanjut dan prognosis yang buruk akan fungsi penglihatan. ${ }^{(4)}$ Penatalaksanaan dini untuk menjernihkan visual axis pada anak dengan leukokoria sangat penting untuk menghindari terjadinya ambliopia. ${ }^{(20)}$

Saat era ketika tatalaksana utama retinoblastoma adalah radiasi, digunakan klasifikasi Reese-Ellsworth yang memisahkan kelas tumor berdasarkan respon terhadap terapi radiasi. Ketika kemoterapi sistemik mulai digunakan sebagai pengganti radiasi dalam penatalaksanaan retinoblastoma, digunakanlah klasifikasi IIRC (International Intraocular Retinoblastoma Classification) dan beberapa klasifikasi lain yang dikembangkan dari IIRC. Klasifikasi lain termasuk staging retinoblastoma ekstraokular dan vitreus seeding. Seperti kanker lain, retinoblastoma juga diklasifikasikan berdasarkan "tumor node metastasis" (TNM). ${ }^{(16)}$

\section{Pemeriksaan penunjang}

USG, CT-Scan dan MRI adalah pemeriksaan penunjang utama yang dilakukan pada pasien anak yang mengalami tumor dibagian kepala dan leher. USG digunakan untuk pemeriksaan tumor yang superfisial seperti retinoblastoma sedangkan CTscan dan MRI digunakan untuk pemeriksaan yang lebih dalam khususnya yang melibatkan tulang dan sistem saraf pusat. Saat ini pemeriksaan yang biasa dilakukan pada pasien yang mengalami retinoblastoma adalah dengan menggunakan funduskopi (dengan anestesi umum), USG dan MRI. ${ }^{(18)}$ Pada hampir semua kasus dapat ditemukan adanya kalsifikasi intratumoral pada pemeriksaan USG yang dapat meyakinkan diagnosis retinoblastoma. Pada retinoblastoma terdapat 
adanya gambaran masa hiperechoic yang ireguler (lebih echogenic dibandingkan badan vitreus) dan gambaran kalsifikasi yang jelas. Kalsifikasi adalah tanda kunci adanya retinoblastoma untuk membedakan dengan massa yang lain pada anakanak. USG dapat mendeteksi adanya kalsifikasi pada 92 - 95\% kasus yang telah dibuktikan secara histologis. Ablasi retina juga dapat terjadi, dimana itu merupakan sebuah gambaran bagaimana tumor tersebut berkembang, apakah secara endofitik ataupun eksofitik. Tumor endofitik berasal dari lapisan dalam retina yang menyebar ke badan vitreus. Terkadang bagian kecil dari tumor tersebut lepas sehingga memberikan gambaran massa yang melayang-layang divitreus atau disebut vitreus seeding. Tumor eksofitik berasal dari lapisan luar retina yang menyebar ke ruang subretina dan menyebabkan ablasi retina. ${ }^{(2,18)}$

Pada pemeriksaan CT-Scan didapatkan gambaran massa dengan densitas yang lebih tinggi dibandingkan badan vitreus dan biasanya terdapat gambaran kalsifikasi. CT-Scan dapat mendeteksi adanya kalsifikasi dengan sensitifitas sebesar 81-96\% atau bahkan lebih. Sensitifitas CT-Scan dalam penggambaran jaringan intraokular yang lebih detail terbatas dan mendeteksi adanya invasi ke nervus optikus juga sangat rendah, bahkan pada invasi ke nervus optikus yang luas. Pemeriksaan MRI adalah pemeriksaan pilihan untuk mengevaluasi massa intraokuler dan menentukan adanya penyebaran atau tidak. MRI telah terbukti sebagai pemeriksaan yang paling sensitif untuk mengevaluasi retinoblastoma, terutama mengenai adanya infiltrasi tumor ke nervus optikus, ekstraokuler dan intrakranial. Pemeriksaan MRI berperan penting dalam menentukan penyebaran lokal dari tumor ataupun mendeteksi abnormalitas pada otak. Pemeriksaan patologi menjadi gold standard untuk menilai kemungkinan metastasis. Anak yang mempunyai gambaran histopatologi yang beresiko tinggi mengalami metastasis membutuhkan adjuvant kemoterapi untuk mengurangi resiko relaps. ${ }^{(18)}$

\section{KESIMPULAN}

Retinoblastoma adalah keganasan intraokular yang paling sering dialami oleh neonatus dan anak-anak. ${ }^{(2,3)}$ Diagnosis dan penanganan retinoblastoma yang terlambat terjadi di negara-negara berkembang termasuk Indonesia mengakibatkan terjadinya metastasis ekstraokular, kehilangan penglihatan dan kematian. ${ }^{(3,4)}$ Adanya hambatan dalam mendiagnosis secara dini pada negara berkembang dikarenakan belum baiknya sistem asuransi kesehatan, kurangnya komunikasi dan kerjasama pihak- pihak yang terlibat, masih terbatasnya peralatan penunjang diagnosis dan kurang efisiennya sistem rujukan. Hambatan lain termasuk faktor pendidikan, kultural dan ekonomi. (9)

Kurangnya edukasi terhadap orang tua dan kurangnya kesadaran tentang tanda dan gejala menyebabkan terlambatnya penanganan medis terhadap pasien. Penyebab lain yaitu orang tua lebih memilih untuk mencari pengobatan alternatif akibat keterbatasan akses maupun alasan kultural yang berdampak keterlambatan mencari pengobatan secara medis..$^{(9)}$

Penanganan optimal retinoblastoma adalah suatu hal yang kompleks dan memerlukan tim yang terdiri dari berbagai macam bidang dan disiplin ilmu. Namun, pembentukan tim yang seperti itu tentu saja akan menghadapi berbagai macam tantangan khususnya pada keadaan dan daerah yang memiliki sumber daya yang terbatas. (11) Hal ini menjadi tantangan bersama untuk menemukan solusi sehingga angka harapan hidup pasien retinoblastoma meningkat terutama di negara- negara berkembang.

\section{KONFLIK KEPENTINGAN}

Penulis menyatakan tidak terdapat konflik kepentingan

\section{REFERENSI}

1. Ali MJ, Honavar SG, Reddy VAP. Orbital retinoblastoma : present status and future challenges- a review. Saudi J Ophthalmol. 2010; 25:159-67.doi:10.1016/j.sjopt.2010.10.010.

2. Grossniklaus HE. Retinoblastoma. fifty years of progress. the LXXI edward jackson memorial lecture. Am J Ophhalmol. 2014; 158(5): 875-91. doi:10.1016/j.ajo.2014.07.025.

3. $\mathrm{Hu} \mathrm{H}$, Zhang W, Wang $\mathrm{Y}$, et al. Characterization, treatment and prognosis of retinoblastoma with central nervous system metastasis. BMC Ophtalmol. 2018;18(107):1-7. doi: 10.1186/ s12886-018-0772-8

4. Abdolvahabi A, Taylor BW, Holden RL,et al.Colorimetric and longitudional analysis of leukocoria in recreational photographs of children with retinoblastoma. Plos One. 2013;8(10):1-14. doi: 10.1371/journal.pone.0076677.

5. Sitorus RS. Sitompul R, Widyawati S, Bani AP. Buku ajar oftamologi : Retinoblastoma. Jakarta : Badan Penerbit Fakultas Kedokteran Universitas 
Indonesia;2017.394-8.

6. Andreoli MT, Chau FY, Shapiro MJ, Leiderman YI. Epidemiological trends in 1,452 cases of retinoblastoma from the surveillance, epidemiology and end result (SEER) registry. Can J Ophthalmol. 2017;52(6):1-20. doi:10.1016/j.jcjo.2017.05.012.

7. Singh L, Kashyap S. Update on pathology of retinoblastoma. Int $\mathrm{J}$ Ophthalmol. 2018;11(12):2011-6. doi:10.18240/ijo.2018.12.22.

8. Ghassemi F, Khodabande A. Risk definition and management strategies in retinoblastoma : current perspectives. Clin Ophthalmol. 2015;9:985-94. doi: 10.2147/OPTH.S59828.

9. Weaver MS, Heminger CL, Lam CG. Integrating stages of changes models to cast new vision on interventions to improve global retinoblastoma and childhood cancer outcomes. BMC Public Health. 2014;14 (944): 1-12.doi:10.1186/14712458-14-944.

10. Dyer MA. Lessons from retinoblastoma : implication for cancer, development, evolution, and regenerative medicine. Trends Mol Med. 2016; 22(10): 1-23. doi: 10.106/j.molmed.2016.07.101.

11. Hill JA, Kimani K, White A, Barasa F, Livingstone M, Gallie BL, et al. Achieving optimal cancer outcomes in East Africa through multidisciplinary partnership : a case study of the Kenyan National Retinoblastoma Strategy group. Globalization and Health. 2016;12(23): 1-11. Doi: 10.1186/s12992016-0160-1.

12. Dimaras H, Corson TW, Cobrinik, White A, Zhao J, Munier FL, et al. Retinoblastoma. J Nat Rev Dis Primers.2017;1:1-54. doi:10.1038/nrdp.2015.21.

13. Hill JA, Lee SY, Njambi L, Corson TW, Dimaras H. Cancer genetics education in a lowto- middle- income country : evaluation of an interactive workshop for clinicians in Kenya. Plos One. 2015;10(6):1-12. doi:10.1371/journal. pone.0129852.

14. Kivela T. Neonatal Retinoblastoma. Asia Pac J Oncol Nurs. 2017;4:197-204. doi:10.4103/apjon. apjon_18_17.

15. Hill JA $\bar{A}$, Gedleh A, Lee S, Hougham KA, Dimaras $\mathrm{H}$. Knowledge, experience and attitudes concerning genetics among retinoblastoma survivors and parents. Eur J Hum Genet. 2018;26:505-17.

16. Dimaras $\mathrm{H}$, CorsonTW. Retinoblastoma, the visible CNS tumor : a review. J Neurosci Res. 2019; 97(1): 29-44. doi: 10.1002/jnr.24213.

17. Rothschild PR, Levy D, Savignoni A, LumbrosoLe Rouic L, Aerts I, Gauthier-Villars M, et al. Familial retinoblastoma : fundus screening schedule impact and guideline proposal. Eye J. 2011;25:1555-61. doi:10.1038/eye.2011.198

18. Graaf PD, Goricke S, Rodjan F, Galluzzi P, Maeder P, Castelijn JA, et al. Guidelines for imaging retinoblastoma: imaging principles and MRI standardization. Pediatr Radiol. 2012; 42: 2-14. doi:10.1007/s00247-011-2201-5.

19. Rodjan F, Graaf PD, Brisse HJ, Goricke S, Maeder P, Galluzzi P, et al. Trilateral retinoblastoma : neuroimaging characteristic and value of routine brain screening on admission. J Neurooncol. 2012; 109: 535-44. doi:10.1007/s11060-012-0922-4.

20. Tartarella MB, Britez-Colombi, Filho JBF Proposal of a novel classification of leukocorias. Clin Ophthalmol. 2012;6:991-5. doi: 10.2147/ OPTH.S31469. 